
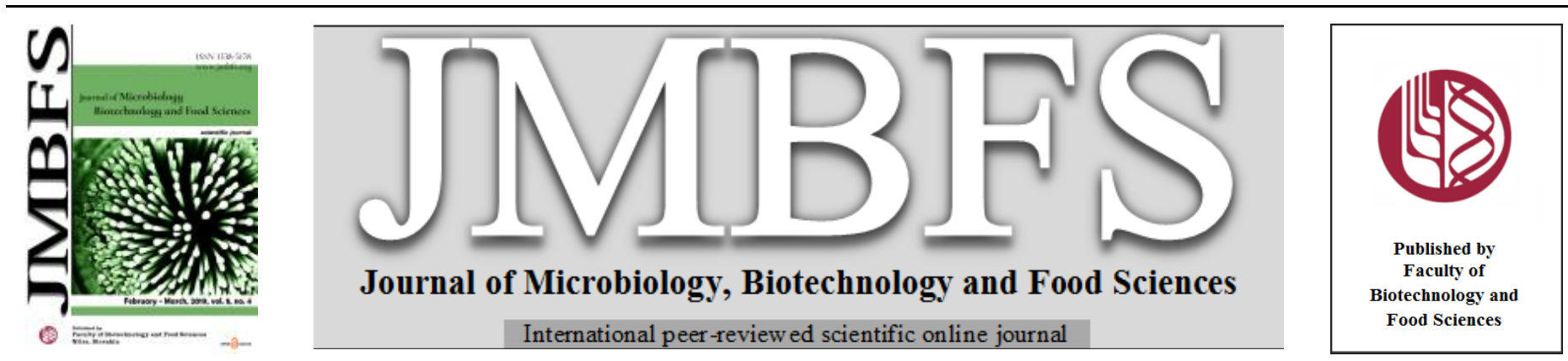

\title{
IMPROVING THE CHITINOLYTIC ACTIVITY OF STREPTOMYCES GRISEORUBENS E44G BY MUTAGENESIS
}

\section{Elsayed Elsayed Hafez ${ }^{1}$, Younes Mohamed Rashad ${ }^{1}$, Waleed Mohamed Abdulkhair ${ }^{2}$, Abdulaziz Abdulrahman Al-Askar ${ }^{3}$, Khalid $^{2}$ Mohamed Ghoneem ${ }^{4}$, Zakaria Awad Baka ${ }^{5}$, Yasser Mohamed Shabana ${ }^{6}$}

\author{
$\operatorname{Address(es):~}$ \\ Borg El-Arab City, Egypt. \\ P.C. 12553, Tel: (+202) 35851278, Fax: (+202) 35851299, Giza, Egypt. \\ ${ }^{3}$ King Saud University, Faculty of Science, Botany and Microbiology Department, Riyadh, Saudi Arabia. \\ ${ }^{4}$ Agricultural Research Center, Plant Pathology Research Institute, Department of Seed Pathology Research, Giza, Egypt \\ ${ }^{5}$ Damietta University, Faculty of Science, Botany Department, Damietta, Egypt. \\ ${ }^{6}$ Mansoura University, Faculty of Agriculture, Plant Pathology Department, Mansoura, Egypt.
}

${ }^{1}$ City of Scientific Research and Technological Applications, Arid Lands Cultivation Research Institute, Plant Protection and Biomolecular Diagnosis Department, New

2* National Organization for Drug Control and Research (NODCAR), General Department of Basic Medical Sciences, Microbiology Department, Elmansoria street,

*Corresponding author: waleed_hamada@yahoo.com

doi: $10.15414 / j m b f s .2019 .8 .5 .1156-1160$

\section{ARTICLE INFO}

Received 9. 4. 2018

Revised 27. 10. 2018

Accepted 14. 12. 2018

Published 1. 4. 2019

Regular article open $\mathcal{O}$ access

\begin{abstract}
Genetic improvement trials of the chitinolytic activity of Streptomyces griseorubens E44G were made by using physical, chemical and site-directed mutagenesis. Although the UV radiation, as a physical mutagen, was shed on the tested bacteria for different durations (5, 10, and $15 \mathrm{~min}$ ), no change in the chitinolytic activity was observed when compared with the wild type. To induce the chemical mutagenesis, S. griseorubens E44G was treated with ethylmethane sulfonate for varied durations (20, 40, and 60 min). The chitinolytic activity decreased with the increment in the exposure period. Four different sets of primers were designed based on the DNA sequence of the wild type of S. griseorubens E44G.Overexpressionof chitinase-encoding genes was observed as three of the amplified mutated genes comparing with the wild-type gene. The chitinolytic activity of the recombinant gene P2 increased by 1.39 -fold comparing with the wild-type gene. The molecular weight of the chitinase protein produced by the mutated gene was determined by SDS-PAGE. In conclusion, these results demonstrated that the recombinant gene of $S$. griseorubens E44G possess a higher level of chitinolytic activity than that of the wild-type. Genetic improvement of the chitinolytic activity of $S$. griseorubens E44G may enhance their biocontrol potential against phytopathogenic fungi.
\end{abstract}

Keywords: Antifungal agents; chemical mutagenesis; physical mutagenesis; site-directed mutagenesis

\section{INTRODUCTION}

Biological control is a good alternative option to the chemical control of plant diseases. Most members of the genus Streptomyces are well known as biocontrol agents against different plant fungal pathogens (Al-Askar et al., 2011; Al-Askar et al., 2015a; Law et al., 2017). The antagonistic mechanisms of Streptomyces sp. include production of specific metabolites such as antibiotics, volatile, nonvolatile compounds and/or hydrolytic enzymes (Evangelista-Martínez, 2014). Chitinase is one of the most important hydrolytic enzymes against fungal pathogens. Chitinases are enzymes that catalyze chitin degradation to its components. The antifungal potentiality of chitinase is related to its ability to degrade the chitin of the fungal cell wall (Swiontek et al., 2014). Involvement of chitinases in the biological control activity of actinomycetes against pathogenic fungi is well documented (Sowmya et al., 2012; Swiontek et al., 2013). Induction of chitinase corresponding gene is an important choice to improve the biocontrol activity against the phytopathogenic fungi. Recently, several chitinase genes from Streptomyces spp. have been characterized and cloned (Nagpure and Gupta, 2013; Jhaet al., 2016). Mutation is one of the most commonly ways to improve the genetic performance of microorganisms. The generally accepted definition of strain improvement is the use of any proper technique that leads to generate of a microorganism exhibiting a desired characteristic. Physical and chemical mutagenshave been used to obtain new microorganisms with improved biocontrol potentiality and/or antibiotics production (Siddique et al., 2014). In order to enhance the antifungal productivity (nystatin)by $S$. noursei NRRL 1714 it was treated with ultraviolet rays (UV) followed by intra-specific protoplas fusion. Among of the obtained 114 mutants, three mutants produced at least $49 \%$ more nystatin than the wild-strain (Khattab and EL-Bondkly, 2006). In this connection, Brautaset et al. (2008) obtained seven improved antifungal polyene macrolides via genetic engineering of the antifungal biosynthesis genes(nystatin)in $S$. noursei. Using spaceflight mutation technique, Liang et al.
(2007) obtained a natamycin producer strain of S. gilvosporeus. In a previous study, we isolated a potent antagonistic bacterial strain from soil in Saudi Arabia which was identified as $S$. griseorubens E44G (Al-Askar et al., 2014). Additional ultrastructural and cytochemical investigation on this strain confirmed its ability to produce chitinase enzyme and proved its contribution to the aggressive nature of this strain (Al-Askar et al., 2015b). The present study aimed to improve the potentiality of this strain for chitinase production and consequently in biocontrol of plant fungal pathogens by using physical, chemical and site-directed mutagenesis (SDM).

\section{MATERIAL AND METHODS}

\section{Microorganism and growth conditions}

A chitinase-producer, S. griseorubens E44G strain, isolated from soil in Saud Arabia, was used in this study. The strain was maintained on a modified nutrient agar medium containing colloidal chitin $5 \mathrm{~g} / \mathrm{L}$, peptone $1 \mathrm{~g} / \mathrm{L}, \mathrm{MgSO}_{4} \cdot 7 \mathrm{H}_{2} \mathrm{O}$ $\mathrm{g} / \mathrm{L},\left(\mathrm{NH}_{4}\right)_{2} \mathrm{SO}_{4} 2 \mathrm{~g} / \mathrm{L}, \mathrm{K}_{2} \mathrm{HPO}_{4} 1 \mathrm{~g} / \mathrm{L}, \mathrm{NaCl} 1 \mathrm{~g} / \mathrm{L}$, trace salt $1 \mathrm{ml} / \mathrm{L}$ and agar 20 $\mathrm{g} / \mathrm{L}$ (Neugebaueret al., 1991). The modified nutrient agar slants were used for growing the bacterium, followed by incubation at $30^{\circ} \mathrm{C}$ for 24 hours to be used.

\section{Mutagenesis using physical and chemical mutagens}

Physical mutagenesis was performed by using UV light according to Khattab and Mohamed, (2012). The UV irradiation was generated by UV lamp ( $254 \mathrm{~nm}$, $\left.0.66 \mathrm{~J} . \mathrm{m}^{-2} \cdot \mathrm{s}^{-1}\right)$. Spore suspensions of S. griseorubens E44G at $2 \times 10^{6} \mathrm{spore} / \mathrm{mL}$ were exposed to UV radiation at a distance of $10 \mathrm{~cm}$ for time periods of 5,10 and $15 \mathrm{~min}$. The spore suspensions were then spread on nutrient agar plates, incubated at $30^{\circ} \mathrm{C}$ for $24 \mathrm{~h}$ then the numbers of colonies were counted and the lethality rate was calculated using the equation below: 


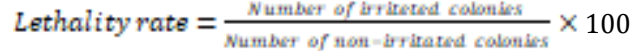

Plates with the highest lethality rate were selected and the colonies were screened for their chitinolytic activity.

Chemical mutagenesis was carried out according to Khattab and Bazaraa, (2005). Spores of $S$. griseorubens $\mathrm{E} 44 \mathrm{G}$ were suspended in phosphate buffer $(0.1$ $\mathrm{M}, \mathrm{pH} 7.5$ ) at $2 \times 10^{6}$ spore/mL Ethyl methane sulfonate (EMS) (Sigma, USA; 200 $\mathrm{mM}$ ) was used as a chemical mutagen. The spores were treated with EMS for 20 40 and $60 \mathrm{~min}$. After which, spores were harvested by centrifugation $(5000 \mathrm{rpm}$, $4^{\circ} \mathrm{C}$ ) and washed twice with phosphate buffer. The spores were then spread on nutrient agar plates and incubated at $30^{\circ} \mathrm{C}$ for $24 \mathrm{~h}$. The plates with the highest lethality rate were selected and the colonies were screened for their chitinolytic activity.

\section{Enzyme source preparation}

The chitinase producing colonies were grown in chitinase liquid medium and incubated at $30^{\circ} \mathrm{C}$ for $72 \mathrm{~h}$ on a rotary shaker. After centrifugation at $5000 \mathrm{rpm}$ for $15 \mathrm{~min}$, the supernatant was collected and used as crude enzyme solution.

\section{Preparation of colloidal chitin}

One-gram chitin (Sigma-Aldrich, USA) was dissolved in $10 \mathrm{~mL}$ conc. $\mathrm{HCl}$ with continuous stirring overnight at $4^{\circ} \mathrm{C}$. Cold ethanol $(400 \mathrm{~mL})$ was then added and left overnight at room temperature. The mixture was centrifuged at $5000 \mathrm{rpm}$ for $20 \mathrm{~min}$, and washed three times with distilled water. The $\mathrm{pH}$ of the mixture was then adjusted to 7 .

\section{Chitinase assay}

To determine the chitinase activity, 0.3-gram colloidal chitin was added to $3 \mathrm{~mL}$ of $50 \mathrm{mM}$ acetate buffer $(\mathrm{pH} 5)$ and incubated with $1 \mathrm{~mL}$ of the crude enzyme at $30^{\circ} \mathrm{C}$ for $1 \mathrm{~h}$. The released monomers were determined by the dinitrosalisylic acid (DNS) method (Miller, 1959).

\section{Amplification of chitinase gene and their sequence analysis}

Total DNA from the wild-type strain was extracted using DNA extraction kit (Qiagen, USA) according to the manufacturer's instructions. The DNA extract was used for amplification of chitinase A gene (chA) using the degenerate primers; CHAF (5- GGN GGN TGG CAN YTN WSN GAY CCN TT -3), CHAR (5- ATR TCN CCR TTR TCN GCR TC -3) according to Hunt et al (2008). The PCR amplification was carried out in a $25 \mu \mathrm{L}$ mixture consist of $2.5 \mu \mathrm{L} 10 x$ Taq DNA polymerase buffer $(10 \mathrm{mM}$ Tris $\mathrm{HCl}(\mathrm{pH} 8.3)$ and $25 \mathrm{mM}$ $\mathrm{KCI}), 2.5 \mu \mathrm{L} 50 \mathrm{mM} \mathrm{MgCl} 2,2 \mu \mathrm{L}$ primer $(40 \mathrm{Pmol} / \mu \mathrm{L})$, and $0.25 \mu \mathrm{L}$ of $\mathrm{Tac}$ polymerase (AmpliTaq, Perkin- Elmer, $5 \mathrm{u} / \mu \mathrm{L}$ ), $2.5 \mu \mathrm{L}$ DNA, $2.5 \mu \mathrm{L}$ dNTPase (4 $\mathrm{mM}$ ) and $12.75 \mu \mathrm{L}$ of $\mathrm{dH}_{2} \mathrm{O}$. The PCR reaction was performed in 9700 thermal cyclers (Perkin-Elmer, Japan) as follows: initial denaturation $95^{\circ} \mathrm{C}$ for $5 \mathrm{~min}$ followed by 40 -cycles $\left(94^{\circ} \mathrm{C}\right.$ for $1 \mathrm{~min} ; 53^{\circ} \mathrm{C}$ for $1 \mathrm{~min}$ and $72^{\circ} \mathrm{C}$ for $2 \mathrm{~min}$; final extension, $72^{\circ} \mathrm{C}$ for $10 \mathrm{~min}$ ). The PCR amplicon was separated on $1 \%$ agarose gel and visualized using gel documentation system. The amplicon was excised from the agarose gel and purified using Qiagen Gel Extraction kit (Qiagen, Germany). The purified DNA was subjected to DNA sequencing and the sequence was analyzed using DNA BLASTn. Using ClustalW 1.82 (Thompson et al., 1994) pairwise and multiple DNA sequence alignment were carried out. Bootstrap neighbor-joining tree was generated using MEGA 3 (Kumar et al., 2004).

\section{SDM}

Based on the obtained DNA sequence of the wild chitinase, four different sets of primers (P1, P2, P3 and P4) were designed using Primer $\mathrm{x}$ program (http://bioinformatics.org/primerx/cgi-bin/protein_4.cgi). Base substitution was carried out in the two sets primers (P2 and P4) while; P1 and P3 were the same primers without the base substitution. The primers were designed to match in different positions (P1 and P2 match at base 32 (form 5') while, $\mathrm{P} 3$ and $\mathrm{P} 4$ match at base 480 (from $5^{\circ}$ ). The base substitution in $\mathrm{P} 2$ was performed in base 23 where the nucleobase $\mathrm{C}$ was substituted by $\mathrm{T}$ which resulted in the conversion of alanine to leucine. In case of P4 the base substitution was performed in base 19 (G-C) which resulted in substitution of alanine by arginine. The DNA was extracted from the bacterial strain as previously describe and subjected to direct PCR using four different primers as previously mentioned using the annealing temperatures described in Table (1). The band intensities of the resultant amplicons were quantified using the software of the gel documentation system (SyengeneBioimaging, In Genius, USA).

\section{Cloning of the chitinase genes}

PCR product resultants were purified using a Qiagene PCR purification kit (Qiagene, Germany). Both chitinase amplicons (wild type and P2) were subjected to cloning using TOPO TA Cloning ${ }^{\circledR}$ (with PCR ${ }^{\circledR} 2.1-$ TOPO $^{\circledR}$ Cloning vector) (Invitrogen ${ }^{\mathrm{TM}}$, USA). DH5 $\alpha$ E. coli was the bacterial strain used in DNA transformation. Using Blue/White colony analysis, the recombinant bacteria were tested. The white colonies were selected and subjected to plasmid DNA extraction separately using QIAgene plasmid minipreb DNA extraction kit (Qiagene, Germany). The plasmid DNA was subjected to PCR analysis using the chitinases specific primers. The well characterized clones were subjected to digestion using Bam $\mathrm{H} 1$ restriction enzyme to release the gene from the PCR $2.1-$ TOPO $^{\circledR}$ vector. Meanwhile, the released fragment was purified by gel extraction kit (Qiagene, Germany) and ligated into the linearized prokaryotic plasmid vector pPROEXHTa (life technologies, USA). The resultant clones were assessed by PCR. The selected recombinant clones were grown in LB medium containing ampicillin as antibiotic $(100 \mathrm{ug} / \mathrm{ml})$. For gene in vitro transcription the recombinant clones were induced when the IPTG was added to the bacterial culture after two hours from the inoculation time. The culture was grown in incubator shaker over night at $37^{\circ} \mathrm{C}$ with shaking at $200 \mathrm{rpm}$ and the cloning was done according to the protocols outlined by Life Technologies, Invitrogen (USA).

\section{Chitinase purification using 6x Histidine affinity-tagged method}

Chitinase purification was carried out using Ni-NTA resin matrix (Qiagene Inc., USA). The induced bacterial cells were pelleted and resuspended in 4 volumes of lysis buffer [50 mM Tris- $\mathrm{HCl}, 5 \mathrm{mM}$ 2-mercaptoethanol, $1 \mathrm{mM}$ PMSF]. The suspension was sonicated until $80 \%$ of the cell was completely disintegrated (the sonication cycle was; $30 \mathrm{sec}$ on and $30 \mathrm{sec}$ off and rest for $5 \mathrm{~min}$ ). The cell debris was removed by centrifugation at $6000 \mathrm{rpm}$ for $5 \mathrm{~min}$, the supernatant was transferred into a new tube (crude supernatant). Chitinase purification was performed according to the protocols of Life Technologies, Invitrogen using the His Tag Column. The activities of the wild type chitinase and the P2 mutated chitinase were subjected to chitinase assay.

Sodium dodecyl sulphate-polyacrylamide gel electrophoresis (SDS-PAGE)

SDS-PAGE was carried out for the purified recombinant chitinase (wild and mutated P2)using the discontinuous buffer system as described by Sambrook $\boldsymbol{e}$ al. (1989).

\section{RESULTS AND DISCUSSION}

\section{Physical and chemical mutagenesis}

UV radiation of $S$. griseorubens E44G for the time duration of 5, 10 and $15 \mathrm{~min}$ resulted in 57,62 , and $87 \%$ lethality rates, respectively. The increase in the time duration of UV radiation led to a decrease in the number of mutant colonies of $S$ griseorubens E44G. No increase in the chitinolytic activity was observed in the mutants obtained at exposure time of $15 \mathrm{~min}$ as compared to the wild-type strain (Table 2). In case of EMS, the number of mutant colonies of S. griseorubens E44G decreased with the incrementing the exposure period, while the lethality rate increased with the exposure period $(61,75$ and $94 \%$, respectively). On contrary, the chitinolytic activity of the resultant mutants decreased in proportion to the exposure period (Table 2). Strain improvement strategies, especially mutagenesis and screening of hyper-producing mutants are very important in the production of secondary metabolites (Siddique $\boldsymbol{e t}$ al., 2014). UV radiation is the most common physical way to carry out random mutations (Parekh et al., 2000) In our investigation, UV radiation induced the lethality rates, while did not affect the chitinolytic activity of the obtained mutants. In addition to mutagenesis, UV light has a lethal effect on most organisms including bacteria. The UV induction of lethality can be attributed to the formation of thymine dimers in DNA that inhibits DNA replication, and may lead to cell death (Sinha and Häder, 2002) Other types of damage in DNA can be obtained by UV radiation including, modification of individual purine and pyrimidine bases (e.g., deamination, ring cleavage) and the addition of other molecules to the purines and pyrimidines. In contrast, cells can repair damaged DNA. The repairing mechanisms include photo-reactivation, base excision repair, nucleotide excision repair, recombination repair, and double-strand break repair (Rastogi et al., 2010).

EMS is a well-known mutagenic agent; its mode of action encompasses alkylation at nitrogen position 7 of guanosine of the DNA molecule, leading to transition type of mutations. Results of the present study revealed that exposure to EMS enhanced the lethality rate and reduced the chitinolytic activity of the resultant mutants. Our results are in agreement with that of Moturi and Charya, (2010) who recorded a reduction in protease and laccases production in Mucor 
mucedo when it was treated with EMS. The same results were obtained by Kamble and Mulani, (2012) where activities of both acid and alkaline phosphatases of the fungus Tricholoma lascivum decreased with increase in the concentration of EMS when compared with the control. Negative effects of mutations can be deletions of DNA, insertions, or mismatched base pairs. These negative mutations significantly harm the organism. Sometimes these cause a vital gene to be turned off, deleted, or altered so that the protein is no longer functional (Lodish et al., 2000).

\section{Amplification of chitinase gene and their sequence analysis}

Results illustrated in Figure (1) showed a PCR amplicon with a molecular size of $\approx 1450 \mathrm{bp}$. The sequence alignment of the amplified gene revealed that the sequence was identical to the chitinase gene of the Streptomyces sp. C203 (gi125487488) with identity $100 \%$. The obtained DNA nucleotide sequence was deposited in the GenBank database under accession number (KJ466124). The phylogenetic tree was constructed based on the DNA nucleotide sequence of the obtained chitinase gene and other 16 different chitinase genes from different strains of Streptomyces (obtained from NCBI website). The 17 examined chitinase genes are divided into two clusters each cluster contains different groups. Chitinase gene of S. griseorubens E44G is included ina group contains five different chitinase genes. The bootstrap on the branch of the phylogenetic tree revealed that our gene is similar to Streptomyces sp. C203 gene with similarity 92\% (Figure 2). Whenever the phylogenetic tree which constructed based on the deduced amino acid sequence showed that the bootstrap similarity with the Streptomyces sp. C203 gene is 100\% (Figure 3). Chitinases of different molecular sizes were previously isolated by other researchers; 1700 bp (Watanabe et al., 1999), 1383 bp (Gust et al., 2003), and 1458 bp (Dong et al., 2007). Based on the obtained wild chitinase gene, four sets of primers were designed and four amplicons of smaller molecular size than the wild-type were observed. The reduction in size of these amplicons may be attributed to the primers matching.

\section{SDM}

Primers P1, P2, P3 and P4 produced amplicons with different molecular sizes (300, 1000, 1400 and $1000 \mathrm{bp}$, respectively) (Figure 4A, B). The four amplicons obtained by the designed primers are smaller in their molecular sizes than the wild-type. Moreover, overexpression was observed with three of the amplified PCR products compared with the wild type. Band intensities of the resultan amplicons were quantified and the obtained results revealed that DNA concentrations of the produced bands (P1, P2, P3 and P4) were 200, 235, 98 and $222 \mathrm{ng}$, respectively compared with $80 \mathrm{ng}$ for the wild-type strain. The amplicon obtained with primer P2 was selected for cloning and transcription in vitro. The overexpression of the recombinant clone (P2) over the wild-type strain is in agreement with that obtained by Okamoto-Hosoya et al. (2003) when they produced over expressed antibiotic genes in S. lividans using SDM. In this connection, Lobo et al. (2013) recorded that the chitinolytic activity of the recombinant chitinase was higher than that of the wild type. The increment in the chitinolytic activity of the mutated strain may be attributed to the induction in the expression of the chitinase gene i.e. the mutation may affect the regulatory region of the chitinase gene. The same results were obtained by Lu et al. (2002) when they produced three different mutated chitinases and examined their activities on the chitin of Manduca sexta insect.

\section{Chitinase purification and activity assay}

Chitinase enzyme was obtained as a recombinant protein in the cultivation medium at a concentration of $4.2 \mathrm{mg} / \mathrm{L}$. The activity of the recombinant chitinase was investigated against colloidal chitin, which was detected in soluble intracellular extracts from the transformed cells (Table 3). The obtained results revealed a high activity in case of $\mathrm{P} 2$ clone $2.3 \mathrm{U} / \mathrm{mL}$ as compared to the wild type $(1.65 \mathrm{U} / \mathrm{mL})$ showing an increase in the chitinolytic activity by 1.39 -fold.

\section{SDS PAGE the purified chitinase proteins}

The purified chitinases were subjected to SDS-PAGE electrophoresis. The purified protein appeared as a single band with $\approx 46 \mathrm{KDa}$ molecular size in case of the wild-type strain and the P2 clone as well (Figure 5). Tanabe et al. (2000) reported that the molecular size of chitinase enzyme of S. griseus HUT6037 was $49 \mathrm{kDa}$. Moreover, Saadoun et al. (2009) recorded that the molecular size of chitinase enzyme ranged between 39 to $79 \mathrm{KDa}$ when isolated and purified from Streptomyces spp. (Strain $\mathrm{S}_{242}$ ). The obtained results showed that the mutagenesis enhanced the chitinase activity by overexpression of the chitinase protein. These results are in agreement with that of Vetrivel and Dharmalingam, (2000) who studied chitinase production and protein profile of the mutant of S. peucetius and found that the increment in chitinase activity is attributed to enhanced synthesis of the chitinase protein. On the other hand, Apichaisataienchote et al. (2005) attributed the increase in chitinase activity of the recombinant strain SU-1 PFIS319 over the wild type to new expressed protein.

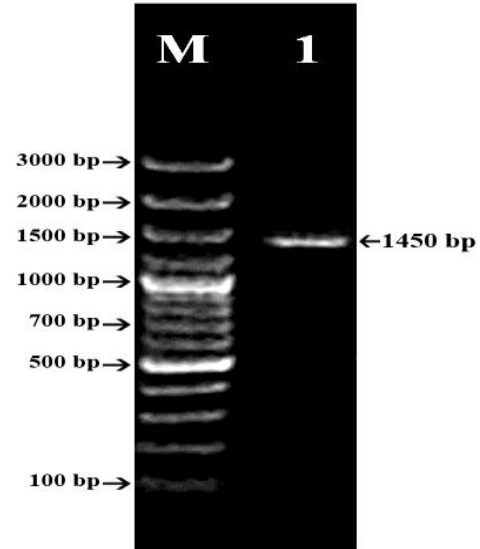

Figure 1PCR amplification of chitinase gene of $S$. griseorubens $\mathrm{E} 44 \mathrm{G} . \mathrm{M}: 3 \mathrm{~Kb}$ DNA Ladder. Lane 1: PCR product of chitinase gene

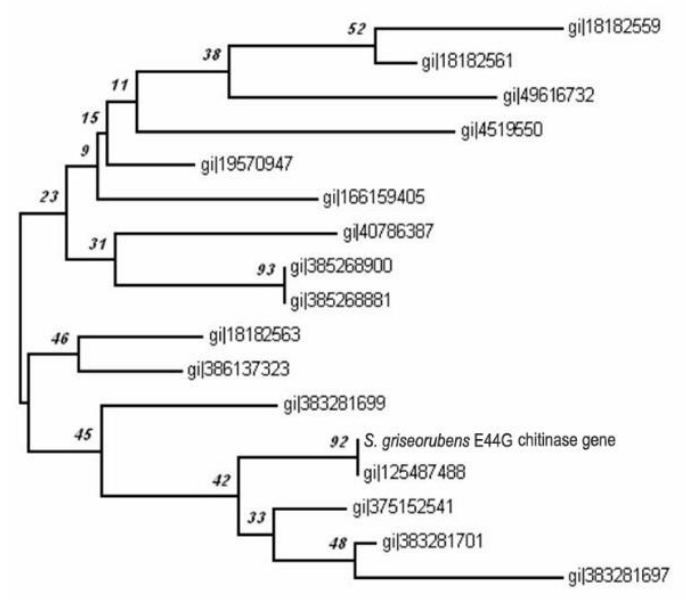

$\stackrel{\longmapsto}{0.01}$

Figure 2 Phylogenetic tree for the isolated chitinase gene of S. griseorubens E44G and other chitinase genes (obtained from NCBI website). The phylogeny was constructed based on the DNA nucleotide sequence and using the Mega 3 programs

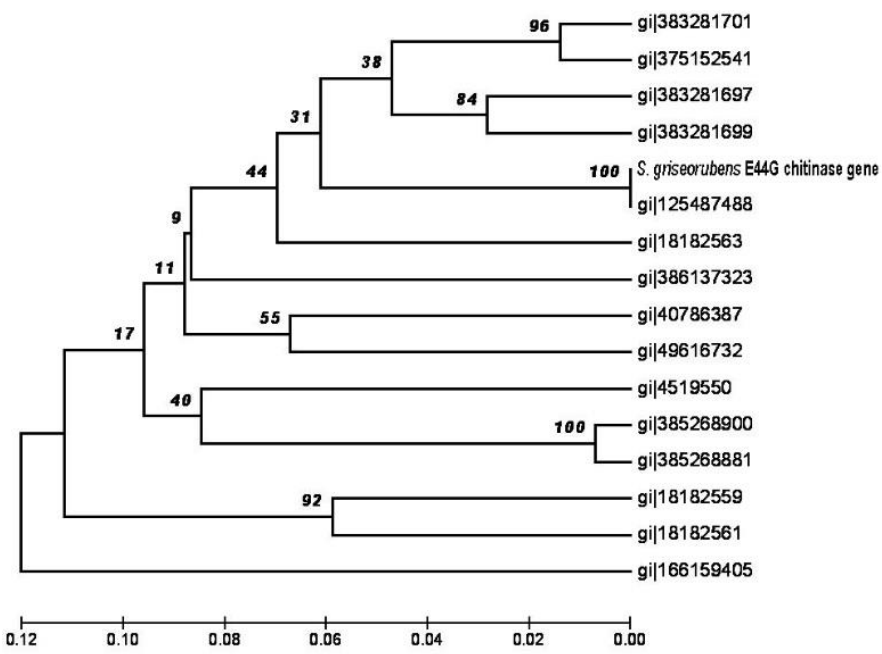

Figure 3 Phylogenetic tree for the isolated chitinase gene of S. griseoruben E44G and the other chitinase genes (obtained from NCBI website). The phylogeny was constructed based on the deduced amino acid sequences and using the Mega 3 programs 


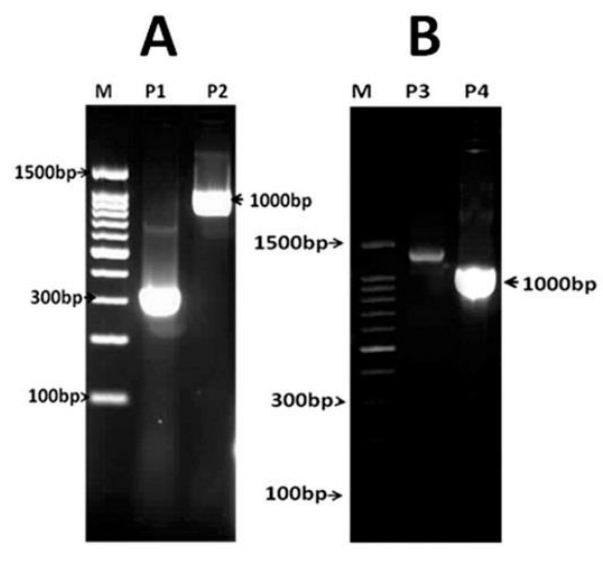

Figure 4 PCR amplification of the chitinase gene of S. griseorubens $\mathrm{E} 44 \mathrm{G}$ using specific primers. A; M: 1.5 DNA Markers. Lanes; P1 and P2; PCR product amplified by primers P1 and P2. B; M: 1.5 DNA Markers. Lanes: P3 and P4 PCR product amplified by primers $\mathrm{P} 3$ and $\mathrm{P} 4$

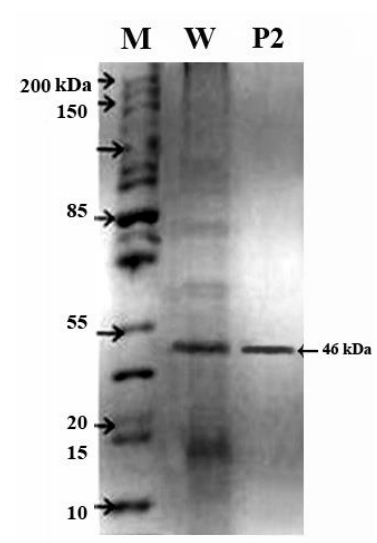

Figure 5 SDS-PAGE for the purified recombinant chitinase genes. M: High range protein marker, lanes; $\mathrm{W}$ : wild chitinase and $\mathrm{P} 2$ : mutated chitinase.

Table 1DNA nucleotide sequence of the primers used in this study

\begin{tabular}{lll}
\hline Primer ID & Sequence`3 to`5 & Annealing Temp. \\
\hline P1F & CGCTTGACACGATCGTCGCTAGCGGAGTCATTTTACCCGCCATC & $56^{\circ} \mathrm{C}$ \\
P1R & GATGGCGGGTAAAATGACTCCGCTAGCGACGATCGTGTCAAGCG & \\
P2F & CGCTTGACACGATCGTCGCTTCTGGAGTCATTTTACCCGCCATC & $56^{\circ} \mathrm{C}$ \\
P2R & GATGGCGGGTAAAATGACTCCAGAAGCGACGATCGTGTCAAGCG & $60^{\circ} \mathrm{C}$ \\
P3F & CGCTTGACACGATCGTCAGTATGGGAGTCATTTTAC \\
P3R & GTAAAATGACTCCCATACTGACGATCGTGTCAAGCG \\
P4F & CGCTTGACACGATCGTCTCTATGGGAGTCATTTTAC & $60^{\circ} \mathrm{C}$ \\
P4R & GTAAAATGACTCCCATAGAGACGATCGTGTCAAGCG & \\
\hline
\end{tabular}

Table 2 Lethality rate and chitinolytic activity of S. griseorubens E44G that exposed to different time durations of physical and chemical mutations

\begin{tabular}{llll}
\hline Mutation & Duration (min) & Lethality rate (\%) & Chitinolytic activity (U/mL) \\
\hline Wild type & - & 0 & $1.68 \pm 0.1$ \\
Physical mutation & 5 & 57 & $1.68 \pm 0.1$ \\
\cline { 2 - 3 } & 10 & 62 & $1.67 \pm 0.2$ \\
\cline { 2 - 3 } & 15 & 87 & $1.66 \pm 0.1$ \\
\cline { 2 - 4 } & 20 & 75 & $1.2 \pm 0.3$ \\
\cline { 2 - 4 } & 40 & 94 & $1.1 \pm 0.1$ \\
\cline { 2 - 4 } & 60 & 75 & $0.97 \pm 0.1$ \\
\end{tabular}

Table 3 Chitinase assay on colloidal chitin substrate

\begin{tabular}{ccc}
\hline Strain type & Chitinolytic activity $(\mathbf{U} / \mathbf{m L})$ & Relative activity $\mathbf{( \% )}$ \\
\hline Wild & $1.65 \pm 0.1$ & 100 \\
\hline Mutated P2 & $2.3 \pm 0.2$ & 139 \\
\hline
\end{tabular}

\section{CONCLUSION}

Results of the present study demonstrated that physical and chemical mutagenesis failed to improve the chitinolytic activity of $S$. griseorubens E44G. On the contrary, the modified recombinant chitinase gene (P2) showed a high level of activity as compared to the wild type. The availability of enzyme preparations of high chitinase activity could be useful not only in biological control but also in bioconversion of the chitin waste materials and in production of chitooligosaccharides for various applications.

Acknowledgments: Authors extend their appreciation to the National Plan for Science, Technology and Innovation, King Abdulaziz City for Science and Technology, KSA.

\section{REFERENCES}

Al-Askar, A. A., Rashad, Y. M., Hafez, E. E., Abdulkhair, W. M., Baka, Z.A., \& Ghoneem, K. M.(2015a).Characterization of Alkaline Protease Produced by Streptomyces griseorubens E44G and Its Possibility for Controlling Rhizoctonia
Root Rot Disease of Corn. Biotechnology and Biotechnological Equipments, 29(3), 457-462. https://doi.org/10.1080/13102818.2015.1015446

Al-Askar, A. A, Baka,Z. A.,Rashad, Y. M., Ghoneem, K.M., Abdulkhair, W.M., Hafez, E.E., \& Shabana Y.M. (2015b). Evaluation of Streptomyces griseorubens E44G for the control of Fusarium oxysporum f. sp. lycopersici: ultrastructural and cytochemical investigations. Annual of Microbiology, 65(4), 18151824.http://dx.doi.org/10.1007/s13213-014-1019-4.

Al-Askar, A. A., Abdulkhair, W. M., \& Rashad, Y. M. (2011). In vitro antifungal activity of Streptomyces spororaveus RDS28 against some phytopathogenic fungi. African Journal of Agricultural Research, 6(12), 2835-2842. http://dx.doi.org/10.5897/AJAR11.320.

Al-Askar, A. A., Abdulkhair, W. M., Rashad, Y. M., Hafez, E. E., Ghoneem, K. M., \& Baka, Z.A. (2014). Streptomyces griseorubens E44G: A potent antagonist isolated from soil in Saudi Arabia. Journal of Pure and Applied Microbiology, 8(Spl. Edn.2), 221-230. http://www.academia.edu/24145361/

Apichaisataienchote, B., Altenbuchner, J., \&Buchenauer, H. (2005). Isolation and identification of Streptomyces fradiae SU-1 from Thailand and protoplast transformation with the chitinase B gene from OPC-131. Current Microbiology, 51(2), 116-121. http://dx.doi.org/10.1007/s00284-005-4402-3.

Brautaset, T., Sletta, H., Nedal, A., Borgos, S. E., Degnes, K. F., Bakke, I., Volokhan, O., Sekurova, O. N., Treshalin, I. D., Mirchink, E. P., Dikiy, A., Ellingsen, T. E., \&Zotchev, S. B. (2008). Improved antifungal polyene macrolides via engineering of the nystatin biosynthetic genes in Streptomyces

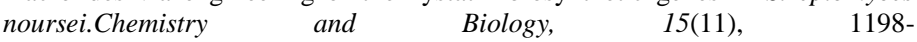
1206.http://dx.doi.org/10.1016/j.chembiol.2008.08.009. 
Dong, L. Q., Yang, J. K., \&Zhang, K. Q. (2007). Cloning and phylogenetic analysis of the chitinase gene from the facultative pathogen Paecilomyces lilacinus. Journal of Applied Microbiology, 103(6), 2476-2488. http://dx.doi.org/10.1111/j.1365-2672.2007.03514.x.

Evangelista-Martínez, Z. (2014). Isolation and characterization of soil Streptomyces species as potential biological control agents against fungal plant pathogens. World Journal of Microbiology and Biotechnology, 30(5), 1639-1647. http://dx.doi.org/10.1007/s11274-013-1568-x.

Gust, B., Challis, G. L., Fowler, K., Kieser, T., \&Chater, K. F. (2003). PCR targeted Streptomyces gene replacement identifies a protein domain needed for biosynthesis of the sesquiterpene soil odor geosmin. Proceedings of the National Academy of $\quad$ Sciences,

$1541-1546$ http://dx.doi.org/10.1073/pnas.0337542100.

Hunt, D. E., Gevers, D., Vahora, N. M., \&Polz, M. F. (2008). Conservation of the chitin utilization pathway in the Vibrionaceae. Applied and Environmental Microbiology, 74(1), 44-51.http://dx.doi.org/10.1128/AEM.01412-07.

Jha, S., Modi, H.A. \& Jha, C.K. (2016). Characterization of extracellular chitinase produced from Streptomyces rubiginosus isolated from rhizosphere of Gossypium sp., Cogent Food \& Agriculture, 2: 1198225 https://doi.org/10.1080/23311932.2016.1198225

Kamble, V. R., \&Mulani, R. M. (2012). Mutation studies in ECM fungus Tricholoma lascivum (Fr.) Gillet from Maharashtra. Bioscience International, 1(3), 66-73. https://www.researchgate.net/publication/259841622

Khattab, A. A., \&Bazaraa, W. A. (2005). Screening, mutagenesis and protoplast fusion of Aspergillus niger for the enhancement of extracellular glucose oxidase production. Journal of Industrial Microbiology and Biotechnology, 32(7), 289294. http://dx.doi.org/10.1007/s10295-005-0249-7.

Khattab, A. A., \& EL-Bondkly, A. M. (2006). Construction of superior Streptomyces noursei fusants for nystatin and antibacterial antibiotics production Arab Journal of Biotechnology, 9(1), 95-106.

Khattab, A. A., \& Mohamed, S. A. A. (2012). Mutation induction and protoplast fusion of Streptomyces spp. for enhanced alkaline protease production. Journal of Applied Sciences Research, 8(2), 807-814. https://doi: 10.3923/biotech.2008.456.462

Kumar, S., Tamura, K., \&Nei, M. (2004). MEGA3: integrated software for molecular evolutionary genetics analysis and sequence alignment. Brief of Bioinform, 5(2), 150-163. https://doi.org/10.1093/bib/5.2.150

Law, JW-F., Ser, H-L., Khan, T.M., chuah, L-H. et al. (2017). The Potential of Streptomyces as Biocontrol Agents against the Rice Blas Fungus, Magnaporthe oryzae(Pyricularia oryzae). Frontiers in Microbiology. 8,3. http://dx.doi.org/10.3389/fmicb.2017.00003.

Liang, J. L., Lin, J. P., Xu, Z. N., Su, W., \& Cen, P. L. (2007). Space-flight mutation of Streptomyces gilvosporeus for enhancing natamycin production. Chinese Journal of Chemical Engineering, 15(5), 720-724. https://dx.doi.org/10.1016/S1004-9541(07)60152-9.

Lobo, M. D., Silva, F. D., Landim, P. G., da Cruz, P. R., de Brito, T. L., de Medeiros, S. C., Oliveira, J. T., Vasconcelos, I. M., Pereira, H. D., \&Grangeiro, T. B. (2013). Expression and efficient secretion of a functional chitinase from Chromobacterium violaceum in Escherichia coli. BMC Biotechnology, 13 46.https://dx.doi.org/10.1186/1472-6750-13-46.

Lodish, H., Berk, A., Zipursky, S. L., Matsudaira, P., Baltimore, D.,\& Darnell, J. (2000). Molecular Cell Biology (4 ${ }^{\text {th }}$ edition). New York: W.H. Freeman doi:10.1016/s1470-8175(01)00023-6

Lu, Y., Zen, K. C., Muthukrishnan, S., \& Kramer, K. J. (2002). Site-directed mutagenesis and functional analysis of active site acidic amino acid residues D142, D144 and E146 in Manduca sexta (tobacco hornworm) chitinase. Insect Biochemistry and Molecular Biology, 32(11), 1369-1382. https://doi.org/10.1016/S0965-1748(02)00057-7

Miller, G. L. (1959). Use of dinitrosalisylic acid reagent for determination of reducing sugar. Annals of Chemistry, 31(3), 426429.https://dx.doi.org/10.1021/ac60147a030.

Moturi, B., \&Charya, M. A. S. (2010). Influence of physical and chemical mutagens on dye decolorizing Mucor mucedo. African Journal of Microbiology Research, 4(17), 1808-1813. https://doi:10.5897/AJMR

Nagpure, A., \& Gupta, R. K. (2013). Purification and characterization of an extracellular chitinase from antagonistic Streptomyces violaceusniger. Journal of Basic Microbiology, 53(5), 429-439.https://dx.doi.org/10.1002/jobm.201100648.

Neugebauer, E., Gamache, B., Dery, C. V., \& Brzezinski, R. (1991). Chitinolytic properties of Streptomyces lividans. Archives of Microbiology, 156(3), 192-197. https://doi.org/10.1007/BF00249114

Okamoto-Hosoya, Y., Okamoto, S., \& Ochi, K. (2003). Development of antibiotic-overproducing strains by site-directed mutagenesis of the $r p s L$ gene in Streptomyces lividans. Applied and Environmental Microbiology, 69(7), 42564259. DOI: 10.1128/AEM.69.7.4256-4259.2003

Parekh, S., Vinci, V. A., \& Strobel, R. J. (2000). Improvement of microbial strains and fermentation processes. Applied Microbiology and Biotechnology, 54(3), 287-301. https://doi.org/10.1007/s002530000403

Rastogi, R. P., Richa, K. A., Tyagi, M. B., \& Sinha, R. P. (2010). Molecular mechanisms of ultraviolet radiation-induced DNA damage and repair. Journal of Nucleic Acids, 2010(2010), 1-32. http://dx.doi.org/10.4061/2010/592980.
Saadoun, I., AL-Omari, R., Jaradat, Z., \&Ababneh, Q. (2009). Influence of culture conditions of Streptomyces sp. (Strain S242) on chitinase production. Polish Journal of Microbiology, 58(4), 339-345. PubMed PMID: 20380144 Sambrook, J., Fritsch, E. F., \&Maniatis, T. (1989). Molecular cloning: A Laboratory Manual ( $2^{\text {nd }}$ edition). New York: Cold Spring Harbor Laboratory. DOI:https://doi.org/10.1016/0167-7799(91)90068-S

Siddique, S., Syed, Q., Adnan, A., \& Qureshi, F. A. (2014). Production and screening of high yield Avermectin B1b mutant of Streptomyces avermitilis 41445 through mutagenesis. Jundishapur Journal of Microbiology, 7(2), e8626. http://dx.doi.org/10.5812/ijm.8626.

Sinha, R. P., \&Häder, D. P. (2002). UV-induced DNA damage and repair: a review. Photochemical and Photobiological Sciences, 1(4), 225-236. https://DOI:10.1039/B201230H

Sowmya, B., Gomathi, D., Kalaiselvi, M., Ravikumar, G., Arulraj, C., \& Uma, C. (2012). Production and purification of chitinase by Streptomyces sp. from soil Journal of Advanced Scientific Research, 3(3), 25-29.

Swiontek, M., Jankiewicz, U., Burkowska, A., \& Walczak, M. (2014). Chitinolytic Microorganisms and Their Possible Application in Environmental Protection. Current Microbiology, 68(1), 71-81.http://dx.doi.org/10.1007/s00284 013-0440-4.

Swiontek, M., Jankiewicz, U., \& Walczak, M. (2013). Biodegradation of chitinous substances and chitinase production by the soil actinomycete Streptomyces rimosus. International Journal of Biodeterioration and Biodegradation, 84, 104-110. https://dx.doi.org/10.1016/j.ibiod.2012.05.038.

Tanabe, T., Kawase, T., Watanabe, T., Uchida, Y., \&Mitsu-tomi, M. (2000). Purification and characterization of a $49 \mathrm{KDa}$ chitinase from Streptomyces griseus HUT 6037. Journal of Bioscience and Bioengineering, 89(1), 27-32. https://doi.org/10.1016/S1389-1723(00)88046-9

Thompson, J. D., Higgins, D. G., \& Gibson, T. J. (1994). Clustal W: improving the sensitivity of progressive multiple sequence alignment through sequence weighting, position-specific gap penalties and weight matrix choice. Journal of Nucleic Acids Research, 22(22), 4673-4680. https://doi: 10.1093/nar/22.22.4673

Vetrivel, K. S., \&Dharmalingam, K. (2000). Isolation of a chitinase overproducing mutant of Streptomyces peucetius defective in daunorubicin biosynthesis. Canadian Journal of Microbiology, 46(10), 956-960. https://doi.org/10.1139/w00-079

Watanabe, T., Kanai, R., Kawase, T., et al. (1999). Family 19 chitinases of Streptomyces species: characterization and distribution. Journal of Microbiology, 145(Pt 12), 3353-3363. https://dx.doi.org/10.1099/00221287-145 $\underline{12-3353}$. 